\title{
Efisiensi Asuransi Syariah di Indonesia dengan pendekatan Data Envelopment Analysis
}

\section{Islamic Insurance Efficiency in Indonesia using Data Envelopment Analysis Approach}

\author{
Mustica Bintang Sabiti ${ }^{1}$, Jaenal Effendi ${ }^{2}$, Tanti Novianti ${ }^{3}$ \\ ${ }^{1}$ Alumnus Program Studi Ilmu Ekonomi Syariah, Institut Pertanian Bogor, E-mail: \\ mustica3595@gmail.com \\ ${ }^{2}$ Dosen Program Studi Ilmu Ekonomi Syariah, Institut Pertanian Bogor, E-mail: \\ jaenfendi@googlemail.com \\ ${ }^{3}$ Dosen Program Studi Ekonomi Studi Pembangunan, Institut Pertanian Bogor, E-mail: \\ tantinovianti@yahoo.com
}

\begin{abstract}
The purpose of this study is to estimate the efficiency level of Islamic insurance companies in Indonesia. The data used are taken from each financial report of 14 Islamic life insurance companies and 12 Islamic general insurance in the period 2013-2015. Efficiency score estimation is done by using Data Envelopment Analysis (DEA) method. There are three input variables, namely asset, load, claim payment and two output variables, namely income and tabarru' funds obtained. The results show that islamic life insurance and islamic general insurance companies in Indonesia have not been operating efficiently.
\end{abstract}

Keywords : DEA, Efficiency, Islamic Insurance

Abstrak. Tujuan dari penelitian ini yaitu untuk mengestimasi tingkat efisiensi perusahaan asuransi syariah di Indonesia. Data yang digunakan diambil dari masing-masing laporan keuangan 14 perusahaan asuransi jiwa syariah dan 12 asuransi umum syariah pada periode 2013-2015. Estimasi skor efisiensi dilakukan dengan menggunakan metode Data Envelopment Analysis (DEA). Terdapat tiga variabel input yaitu aset, beban, pembayaran klaim dan dua variabel output yaitu pendapatan dan dana tabarru' yang diperoleh. hasil menunjukkan bahwa perusahaan asuransi jiwa syariah dan asuransi umum syariah di Indonesia belum mencapai tingkat efisien.

Kata kunci : DEA, Efisiensi, Asuransi Syariah

\section{Pendahuluan}

Industri asuransi syariah yang masih tergolong dalam infant industry, secara global semakin berkembang dan mengalami pertumbuhan yang cukup baik. Hal ini dibuktikan dengan adanya peningkatan kontribusi asuransi syariah global pada periode tahun 2012 sampai 2015. Gambar 1 memperlihatkan adanya peningkatan total aset perbankan syariah, islamic fund, jumlah sukuk outstanding, dan kontribusi asuransi syariah secara global. Jika dilihat secara umum masingmasing sektor industri mengalami peningkatan dengan perbankan syariah sebagai sektor yang paling mendominasi. Sukuk menempati posisi kedua dan islamic fund menempati posisi ketiga. Asuransi syariah yang belum lama mengalami perkembangan menempati posisi terakhir. Meskipun demikian sektor asuransi syariah memperlihatkan perkembangan jumlah kontribusi yang cukup baik dan selalu mengalami peningkatan. 


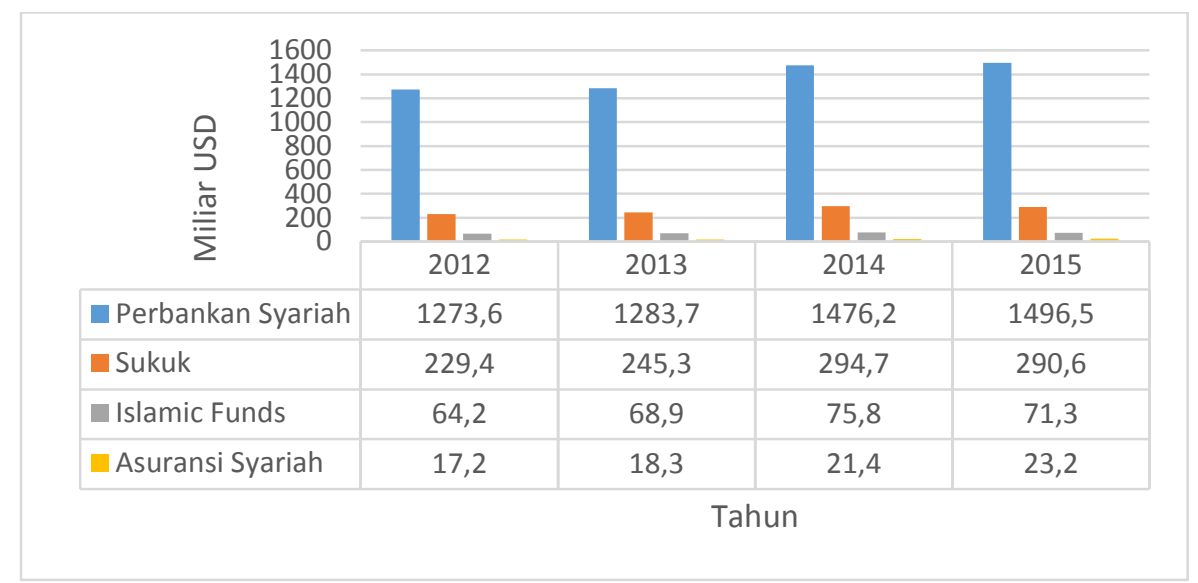

Sumber : IFSB (2016, diolah)

\section{Gambar 1 Perkembangan industri keuangan syariah global}

Menurut laporan World Takaful Report (2016) pasar asuransi syariah secara global terkonsentrasi pada negara anggota GCC dan Asia Tenggara. Kontribusi bruto asuransi syariah di negara Asia Tenggara menempati posisi kedua terbesar setelah negara Saudi Arabia (EY 2014). Berdasarkan data yang telah dirilis oleh EY (2014) besarnya jumlah kontribusi bruto asuransi syariah di Asia Tenggara didominasi oleh negara Malaysia sebesar 71, $28 \%$ dan negara Indonesia sebesar 22, 72\% dan sisanya negara lainnya. Hal ini dikarenakan populasi masyarakat muslim di kedua negara tersebut cukup banyak, selain itu Malaysia merupakan salah satu negara yang gencar dalam mengembangkan asuransi syariah.

Indonesia sebagai penyumbang kontribusi bruto asuransi syariah terbesar kedua di Asia Tenggara tentu memiliki potensi yang cukup besar. Hal ini mengindikasikan bahwa pertumbuhan premi perusahaan asuransi syariah di Indonesia semakin berkembang dan menguatkan posisinya di pasar asuransi Indonesia yang merupakan negara berpenduduk muslim terbesar di dunia. Hal ini didukung dengan peningkatan jumlah perusahaan asuransi syariah dan unit usaha syariah yang ditunjukkan pada Tabel 1. 
Tabel 1 Perkembangan jumlah perusahaan asuransi syariah di Indonesia periode 20112016

\begin{tabular}{lcccccc}
\hline \multicolumn{1}{c}{ Keterangan } & 2011 & 2012 & 2013 & 2014 & 2015 & 2016 \\
\hline $\begin{array}{l}\text { Perusahaan Asuransi Jiwa } \\
\text { dengan Prinsip Syariah }\end{array}$ & 3 & 3 & 3 & 3 & 5 & 6 \\
$\begin{array}{l}\text { Perusahaan Asuransi Kerugian } \\
\text { dengan Prinsip Syariah }\end{array}$ & 2 & 2 & 2 & 2 & 3 & 4 \\
$\begin{array}{l}\text { Perusahaan Asuransi Jiwa yang } \\
\text { memiliki Unit Syariah }\end{array}$ & 17 & 17 & 17 & 18 & 19 & 21 \\
$\begin{array}{l}\text { Perusahaan Asuransi Kerugian } \\
\text { yang memiliki Unit Syariah }\end{array}$ & 18 & 20 & 24 & 23 & 25 & 24 \\
$\begin{array}{l}\text { Perusahaan Reasuransi dengan } \\
\text { Prinsip Syariah } \begin{array}{l}\text { Perusahaan Reasuransi yang } \\
\text { memiliki Unit Syariah }\end{array}\end{array}$ & 0 & 0 & 0 & 0 & 0 & 1 \\
Jumlah & 4 & 3 & 3 & 3 & 3 & 2 \\
\hline
\end{tabular}

Sumber : Statistik Perasuransian OJK (2016)

Tabel 1 menunjukkan bahwa jumlah perusahaan asuransi syariah baik yang berupa unit usaha ataupun perusahaan asuransi syariah full fledge secara umum mengalami peningkatan selama periode 2011-2016. Perusahaan asuransi jiwa syariah full fledge mengalami peningkatan menjadi enam perusahaan, sedangkan perusahaan asuransi jiwa yang memiliki unit syariah meningkat menjadi 21 perusahaan di tahun 2016. Selain itu perusahaan asuransi kerugian yang memiliki unit syariah menjadi 24 perusahaan, sedangkan perusahaan asuransi kerugian syariah full fledge mengalami peningkatan menjadi empat perusahaan. Meningkatnya jumlah perusahaan asuransi syariah full fledge dikarenakan adanya spin off unit syariah dari perusahaan asuransi konvensional menjadi perusahaan asuransi syariah full fledge. Selain itu peningkatan jumlah unit asuransi syariah baik asuransi jiwa ataupun kerugian didorong oleh perusahaan asuransi konvensional yang menyediakan layanan asuransi syariah sehingga dibukalah unit asuransi syariah. Di sisi lain jumlah perusahaan reasuransi syariah tidak mengalami perubahan.

Prospek industri asuransi syariah diprediksikan akan terus mengalami perkembangan di masa yang akan datang. Berdasarkan laporan Global Takaful Insight 2014, industri asuransi syariah global mengalami pertumbuhan sebesar $14 \%$ setiap tahunnya. Di samping itu pertumbuhan ekonomi yang cukup stabil di Indonesia diprediksikan akan meningkatkan jumlah kelas menengah (Ramadhani 2015). Seperti data yang dirilis oleh Boston Consulting Group (2013) yang menyatakan bahwa jumlah populasi kelas menengah di Indonesia diprediksi akan mencapai 141 juta di tahun 2020. Selain itu berdasarkan survei literasi keuangan yang dilakukan oleh OJK pada tahun 2016 menyebutkan bahwa tingkat pemahaman masyarakat terhadap asuransi sebesar $15.76 \%$. Meningkatnya jumlah kaum menengah dan pemahaman masyarakat tentang asuransi tentunya akan memperluas target pasar bagi industri asuransi syariah.

Tingkat persaingan yang semakin ketat dan besarnya potensi asuransi syariah nasional yang belum tergarap dengan baik menuntut industri asuransi syariah untuk dapat bersaing dan menunjukkan performa kinerja yang baik. Salah satu penilaian terhadap kinerja perusahaan yaitu dilihat dari efisiensinya. Pengukuran efisiensi merupakan salah satu hal penting untuk 
menilai performa atau kinerja perusahaan asuransi syariah yang mana hal tersebut akan menentukan daya saing industri dalam merespon segala tantangan yang dihadapi. Sehingga perusahaan asuransi syariah dapat menunjukkan performa dan kinerja yang baik dalam menjalankan fungsinya. Pengukuran efisiensi akan mengevaluasi tingkat daya saing perusahaan asuransi syariah yang dilihat dari sisi pengeluaran perusahaan (input) dan sisi pendapatan (output).

Menurut Antonio et al. (2013) pengukuran efisiensi sangat diperlukan untuk mengevaluasi kinerja industri asuransi syariah dan akan menentukan daya saing industri tersebut. Studi di Gulf Cooperation Council (GCC) menyatakan bahwa industri asuransi syariah memiliki tingkat efisiensi teknis dan efisiensi teknis murni yang cukup tinggi, namun tingkat efisiensi biaya sedang dan masih bisa ditingkatkan lagi (Al-Amri 2015). Di sisi lain adanya studi komparatif yang dilakukan Saad (2012) menunjukkan bahwa secara umum efisiensi perusahaan asuransi syariah masih berada di bawah asuransi konvensional.

Penelitian tentang efisiensi perusahaan asuransi syariah di Indonesia sebelumnya pernah dilakukan oleh Tufahati et al. (2016) dengan sampel sebanyak 22 perusahaan yang dianalisis laporan keuangannya dalam periode 2012-2014. Hasil penelitian tersebut menunjukkan bahwa belum ada perusahaan asuransi syariah full fledge yang mencapai tingkat efisiensi optimal, sedangkan pada unit asuransi syariah terdapat dua perusahaan asuransi umum dan empat perusahaan asuransi jiwa yang mencapai efisiensi secara optimal. Akan tetapi dalam penelitian tersebut tidak menganalisis variabel pembayaran klaim yang mana variabel tersebut dapat dianalisis sebagai variabel input serta variabel perolehan dana tabarru' dapat dijadikan variabel output. Oleh karena itu dalam penelitian ini akan diestimasi tingkat efisiensi perusahaan asuransi syariah di Indonesia baik yang bergerak pada industri asuransi umum ataupun asuransi jiwa dengan menggunakan pendekatan orientasi input. Adapun variabel yang digunakan yaitu aset, beban, dan pembayaran klaim sebagai variabel input, sedangkan pendapatan dan perolehan dana tabarru' sebagai variabel outputnya.

\section{Tinjauan Pustaka}

\subsection{Konsep Efisiensi}

Makna efisiensi dalam teori produksi yaitu ketika suatu perusahaan dapat menghasilkan laba maksimal atas produksi yang dilakukan, sedangkan dalam teori konsumsi, efisiensi dimaknai ketika konsumen mampu untuk memaksimalkan kepuasan atau utilitasnya. Dalam proses produksi, efisiensi dimaknai sebagai alat ukur untuk menilai pilihan-pilihan produsen. Farrell (1957) berpendapat bahwa efisiensi produksi pada sebuah perusahaan terdiri dari komponen teknis dan alokatif. Efisiensi teknis (TE) merupakan kemampuan suatu perusahaan untuk berproduksi di sepanjang kurva isoquan sehingga menghasilkan output seoptimal mungkin dengan kombinasi input tertentu. Efisiensi alokatif merefleksikan kemampuan perusahaan menggunakan input dalam proporsi yang optimal, sesuai dengan harga masing-masing dari input tersebut. Kedua pengukuran ini kemudian digabung untuk mengukur efisiensi ekonomi.

Tingkatan efisiensi dapat ditentukan melalui dua pendekatan yaitu pendekatan input dan pendekatan output. Seperti yang dikemukakan oleh Coelli et al. (1998) bahwa pengukuran berorientasi input merupakan kondisi dimana pengurangan penggunaan input akan 
menghasilkan output tertentu, sedangkan orientasi output terjadi saat penggunaan input tertentu akan menghasilkan output yang lebih besar.

Gambar 4 menunjukkan pengukuran efisiensi berorientasi input dimana SS' merupakan unit isoquan yang efisien. Unit isoquan yang efisien menunjukkan kombinasi input $\left(\mathrm{x}_{1}\right.$ dan $\left.\mathrm{x}_{2}\right)$ yang efisien untuk menghasilkan output (y). Sebagai ilustrasi titik $\mathrm{P}$ dan $\mathrm{Q}$ mewakili dua perusahaan asuransi syariah berbeda yang menggunakan kombinasi input dengan proporsi yang sama. Keduanya terletak pada garis yang sama dari titik asal (0) untuk memproduksi satu unit output (y). Titik P terletak di atas isoquan, sedangkan titik Q mewakili perusahaan asuransi syariah yang secara teknis efisien karena berada pada frontier. Titik $Q$ menunjukkan bahwa perusahaan asuransi syariah menghasilkan output yang sama seperti titik $P$, tetapi dengan jumlah input yang lebih sedikit.

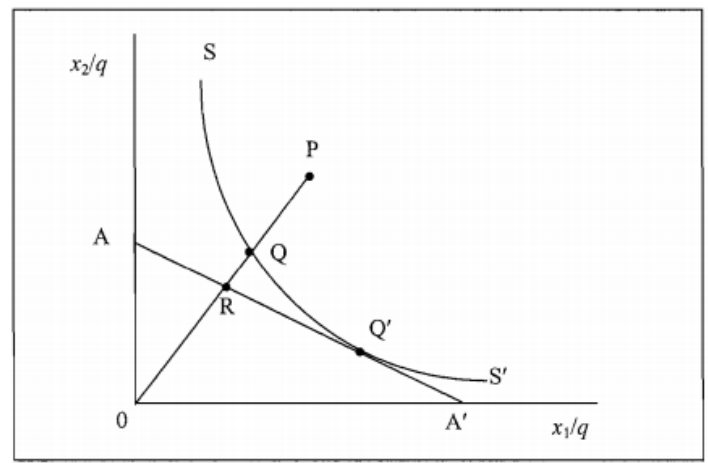

Sumber: Coelli et al. (1998)

\section{Gambar 2 Efisiensi teknis dan alokatif berorientasi input}

Agama Islam telah memerintahkan pada umat manusia untuk berlaku efisien dalam memanfaatkan sumberdaya dan harta bendanya, hal ini telah dijelaskan dalam Al Qur'an.

"Dan berikanlah kepada keluarga-keluarga yang dekat akan haknya, kepada orang miskin dan orang yang dalam perjalanan dan janganlah kamu menghambur-hamburkan (hartamu) secara boros. Sesungguhnya pemboros-pemboros itu adalah saudara-saudara syaitan dan syaitan itu adalah sangat ingkar kepada Tuhannya" (QS Al Isra 26-27)

Berdasarkan ayat di atas telah dijelaskan bahwasannya perilaku boros itu tidak dianjurkan dalam Islam. Jika kandungan ayat tersebut diimplementasikan pada sebuah perusahaan maka dapat dilihat dari kinerja efisiensi perusahaan tersebut untuk melihat apakah sumberdaya (input) dalam perusahaan itu sudah termanfaatkan dengan optimal.

\subsection{Pengukuran Efisiensi}

Secara umum terdapat dua metode dalam mengukur kinerja efisiensi yaitu dengan metode parametrik dan non parametrik. Salah satu aspek pembeda antara dua metode tersebut yaitu dalam metode parametrik menggunakan pendekatan ekonometrik dan memerlukan asumsiasumsi statistik, sedangkan pada metode non parametrik menggunakan pendekatan non ekonometrik yang tidak memerlukan adanya asumsi statistik. Pada pendekatan parametrik terdapat tiga metode yang sering digunakan yaitu Stochastik Frontier Approach (SFA), 
Distribution Free Approach (DFA), dan Thick Frontier Approach (TFA) (Berger \& Humpery 1997).

Adapun pendekatan non parametrik terdapat dua metode yang sering digunakan yaitu Data Envelopment Analysis (DEA) dan Free Disposal Hull (FDH). DEA merupakan teknik pemrograman linier matematis yang digunakan untuk mengevaluasi kinerja efisiensi dari suatu unit pengambil keputusan atau Decision Making Unit (DMU) yang menggunakan sejumlah input untuk menghasilkan output tertentu. Sedangkan FDH merupakan generalisasi dari model DEA, dimana model ini tidak mensyaratkan estimasi frontier. Menurut Bauer et al. (1998) pendekatan dengan menggunakan analisis frontier lebih unggul dibandingkan dengan pendekatan analisis rasio keuangan yang lebih tradisional seperti Return On Asset (ROA) atau cost revenue ratio untuk menilai kinerja perusahaan.

Pada penelitian ini skor efisiensi diestimasi menggunakan metode non parametrik, yaitu DEA. Data Envelopment Analysis (DEA) merupakan salah satu metode non parametrik yang umum digunakan dalam mengestimasi skor efisiensi suatu Decision Making Unit (DMU). Metode ini pertama kali ditemukan oleh Farrell pada tahun 1957 dan kemudian dikembangkan oleh Charnes, Cooper dan Rhodes. Salah satu kelebihan metode ini yaitu dapat menganalisis multi input dan multi output.

Pengukuran efisiensi dengan Data Envelopment Analysis secara umum menggunakan dua model yang sering digunakan. Pertama yaitu model CCR yang diperkenalkan oleh Charnes, Cooper dan Rhodes pada tahun 1978 sehingga sering dikenal dengan model CCR. Dalam model ini berasumsi Constan Return to Scale (CRS) kondisi internal dan eksternal unit pengambil keputusan (DMU) yang akan saling dibandingkan memiliki kondisi yang sama. Setiap perusahaan asuransi syariah yang menjadi unit pengambil keputusan (DMU) akan dibandingkan dengan seluruh DMU yang ada pada sampel. Dalam model ini, perusahaan asuransi syariah pada sampel penelitian diasumsikan memiliki kondisi internal dan eksternal yang sama serta beroperasi di pasar persaingan sempurna.

Akan tetapi terdapat kritik untuk asumsi ini bahwa asumsi CRS hanya sesuai untuk kondisi dimana DMU beroperasi pada skala optimal. Pada faktanya meskipun DMU tersebut beroperasi dengan input yang sama dan menghasilkan output yang sama pula, akan tetapi kondisi internal dan eksternalnya mungkin berbeda sehingga dapat mengakibatkan DMU tersebut tidak beroperasi pada skala optimal. Akibatnya penggunaan model CCR akan menghasilkan nilai efisiensi teknis yang tidak sesuai ketika beberapa DMU tidak beroperasi pada skala optimal. Konsep pendekatan dalam model CCR ini yaitu constan return to scale dimana setiap penambahan input $\mathrm{x}$ kali akan menghasilkan penambahan output $\mathrm{x}$ kali juga.

Kelemahan yang terdapat pada asumsi CRS memunculkan asumsi lain yaitu variable return to scale (VRS) yang merupakan hasil pengembangan dari asumsi constan return to scale. Asumsi ini pertama kali diperkenalkan oleh Baker, Charner dan Cooper, sehingga dikenal dengan model BCC. Pada model ini perusahaan asuransi syariah diasumsikan tidak memiliki kondisi internal dan eksternal yang sama serta tidak beroperasi pada persaingan sempurna. Perusahaan asuransi syariah tidak lagi memiliki return yang konstan (CRS) tetapi model ini mengasumsikan perusahaan tersebut beroperasi dengan variable return to scale. 
Asumsi variable return to scale memiliki makna bahwa penambahan input setiap x kali tidak mengakibatkan output akan bertambah sebesar x kali juga, akan tetapi bisa lebih kecil ataupun lebih besar. Selain itu asumsi VRS menggambarkan technical efficiency secara keseluruhan yang terdiri dari dua komponen yaitu pure technical efficiency (PTE) dan scale efficiency (ES). Pure technical efficiency menggambarkan kemampuan unit pengambil keputusan untuk memanfaatkan sumberdaya yang dimilikinya, sedangkan efisiensi skala menggambarkan suatu unit pengambil keputusan dapat beroperasi pada skala produksi yang tepat.

\section{Metode}

\subsection{Jenis dan Sumber Data}

Data yang digunakan dalam penelitian ini merupakan data sekunder yang berbentuk panel data yaitu gabungan antara data cross section berupa perusahaan asuransi dan reasuransi syariah di Indonesia dan data times series berupa laporan keuangan tahunan periode 2012-2015. Data diperoleh dari situs Otoritas Jasa keuangan (OJK) berupa Statistik Perasuransian Indonesia dan dari situs perusahaan asuransi dan reasuransi syariah berupa Laporan Keuangan. Selain itu dalam penelitian ini juga menggunakan data pelengkap lainnya yang diperoleh dari literatur yang berkaitan, buku, jurnal dan media internet.

\subsection{Metode Analisis dan Pengolahan Data}

Metode analisis data yang digunakan dalam penelitian ini adalah analisis deskriptif dan analisis kuantitatif. Analisis deskriptif dilakukan dengan tujuan untuk mengeksplorasi dan klarifikasi suatu permasalahan. Di sisi lain analisis kuantitatif yang digunakan dalam penelitian ini melalui metode Data Envelopment Analysis (DEA) yang digunakan untuk menghitung skor efisiensi perusahaan asuransi syariah.

\subsubsection{Data Envelopment Analysis (DEA)}

Metode Data Envelopment Analysis (DEA) digunakan untuk menghitung skor efisiensi teknis, efisiensi teknis murni, dan skala efisiensi. Pendekatan yang digunakan dalam penelitian ini yaitu pendekatan intermediasi dengan orientasi input. Orientasi input menghasilkan skor efisiensi yang memperhitungkan kemampuan perusahaan untuk menggunakan sejumlah kombinasi input optimal dalam menghasilkan output tertentu. Pemilihan orientasi input ini dikarenakan perusahaan asuransi lebih baik mengoptimalkan perusahaannya agar dapat bekerja secara optimal pada pangsa pasarnya sendiri sehingga akan lebih mudah bersaing dengan perusahaan lainnya.

Skor efisiensi teknis, efisiensi teknis murni, dan skala efisiensi berkisar antara 0-1. Perusahaan akan dikatakan efisien jika skor efisiensinya mendekati angka 1, dan dikatakan tidak efisien jika skor mendekati 0 . Terdapat empat input dan dua output yang digunakan dalam penelitian ini yang dijelaskan pada Tabel 2. 
Tabel 2 Definisi operasional variabel input dan output

\begin{tabular}{|c|c|c|}
\hline Variabel & Definisi & Rujukan \\
\hline \multicolumn{3}{|l|}{ Input } \\
\hline Aset & $\begin{array}{l}\text { Keseluruhan dari aset lancar dan aset } \\
\text { tidak lancar. }\end{array}$ & $\begin{array}{l}\text { Tufahati et al. (2016), Miniaoui } \\
\text { dan Chaibi (2012), Khan dan } \\
\text { Noreen (2014), Benarda et al. } \\
\text { (2016) }\end{array}$ \\
\hline Beban & $\begin{array}{l}\text { Terdiri dari beban komisi, ujroh } \\
\text { dibayar, beban umum dan administrasi, } \\
\text { beban pemasaran, dan beban } \\
\text { pengembangan. }\end{array}$ & $\begin{array}{l}\text { Saad et al. (2006), Miniaoui dan } \\
\text { Chaibi (2014), Antonio et al. } \\
\text { (2013), Rahman (2013), Khan dan } \\
\text { Noreen (2014), Al-Amri (2015), } \\
\text { Benarda et al. (2016), Tufahati et } \\
\text { al. (2016) }\end{array}$ \\
\hline
\end{tabular}

Pembayaran Pembayaran atas permohonan atau Benarda et al. (2016) klaim pengajuan kerugian peserta asuransi yang termasuk dalam beban asuransi.

\begin{tabular}{ll}
\hline Output & \\
Pendapatan & $\begin{array}{l}\text { Penghasilan yang diperoleh dari Benarda et al. (2016) } \\
\text { aktivitas perusahaan, terdiri dari }\end{array}$ \\
& pendapatan pengelolaan operasi \\
& asuransi, pengelolaan portofolio \\
& investasi dana peserta, pembagian \\
& surplus underwriting, dan pendapatan \\
& investasi. \\
\hline Dana tabaru' & Kontribusi premi dari peserta yang Benarda et al. (2016) \\
& akan digunakan untuk meng-cover \\
& setiap kerugian yang muncul di antara \\
& peserta sesuai ketentuan yang ada pada \\
& polis asuransi.
\end{tabular}

\section{Hasil dan Pembahasan}

Asuransi syariah merupakan sebuah usaha yang bergerak dalam pertanggungan risiko. Sebagai unit usaha yang bertanggungjawab dalam mengelola dana tabarru' yang telah dibayarkan oleh peserta asuransi tentu saja perusahaan asuransi syariah dituntut untuk menampilkan performa kinerja perusahaan yang baik. Kinerja perusahaan yang baik tentu akan berdampak pada trust masyarakat pada perusahaan asuransi syariah. Di samping itu perusahaan asuransi syariah akan mampu bertahan dan bersaing dengan industri asuransi konvensional yang telah lebih dulu berkembang. 
Analisis efsiensi industri asuransi syariah pada penelitian ini akan dibagi menjadi dua bagian, yaitu yang pertama akan membahas tingkat efisiensi asuransi jiwa syariah dan kedua akan membahas tingkat efisiensi pada asuransi umum syariah di Indonesia. Secara umum berdasarkan hasil pengolahan data laporan keuangan dari 26 perusahaan asuransi syariah pada periode 2013-2015 menunjukkan bahwa perusahaan asuransi syariah belum beroperasi secara efisien.

Gambar 3 menunjukkan tren rata-rata efisiensi asuransi syariah di Indonesia periode 20132015. Hasil pengukuran efisiensi yang meliputi efisiensi teknis keseluruhan (TE), teknis murni (PTE) dan efisiensi skala (ES) rata-rata belum mencapai skor sempurna. Hal ini mengindikasikan bahwa sebagian besar perusahaan asuransi syariah di Indonesia belum beroperasi secara efisien. Terlihat bahwa pengukuran efisiensi dibawah asumsi variable return to scale (VRS) yang menghasilkan efisiensi teknis murni (PTE) cenderung mengalami peningkatan dari tahun 2013-2015. Di sisi lain pengukuran efisiensi dibawah asumsi constan return to scale (CRS) yang menghasilkan nilai efisiensi teknis (TE) mengalami penurunan ditahun 2014 kemudian meningkat kembali ditahun 2015. Demikian pula dengan nilai efisiensi skala (ES) yang memiliki tren sama dengan efisiensi teknis. Hal ini dikarenakan nilai ES berasal dari nilai TE dibagi dengan PTE.

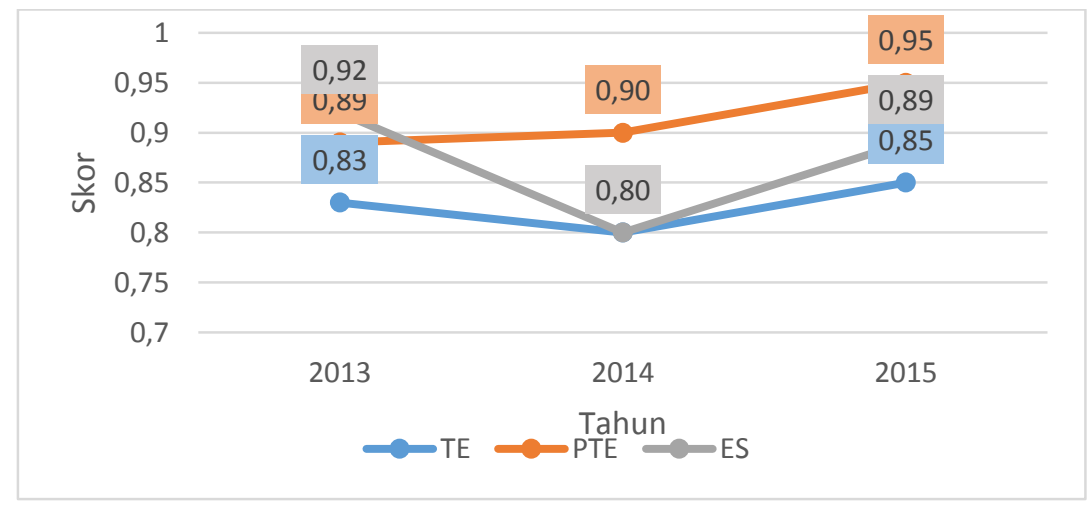

Sumber : Output DEA (2017, diolah)

\section{Gambar 3 Tren efisiensi asuransi syariah di Indonesia periode 2013-2015}

\subsection{Asuransi Jiwa Syariah}

Sebelum masuk ke pembahasan efisiensi asuransi jiwa syariah di Indonesia berikut ini merupakan gambaran umum mengenai variabel input dan output dalam kegiatan operasional asuransi jiwa syariah di Indonesia yang kemudian akan digunakan untuk mengestimasi skor efisiensi. Ada tiga input yang digunakan dalam penelitian ini yaitu aset, beban dan pembayaran klaim, sedangkan output yang digunakan yaitu pendapatan dan dana tabarru'. Tabel 3 menunjukkan statistik diskriptif input dan output yang digunakan dalam penelitian ini.

Tabel 3 Statistik diskriptif input dan output perusahaan asuransi jiwa syariah periode 2013-2015 (dalam juta rupiah)

\begin{tabular}{lrrrr}
\hline \multicolumn{1}{c}{ Variabel } & Rata-rata & Standar deviasi & Nilai Minimum & Nilai Maksimum \\
\hline Input : & & & & \\
\hline Aset & 663277 & 1066395 & 71504 & 5164388 \\
\hline Beban & 130789 & 200792 & 2944 & 647784 \\
\hline & & & & 77
\end{tabular}

Jurnal Al-Muzara'ah Vol.5, No.1, 2017

(ISSN p: 2337-6333;e:2355-4363) 


\begin{tabular}{lrrrr}
\hline Pembayaran klaim & 48465 & 76267 & 1382 & 309402 \\
\hline Output : & & & \\
\hline Pendapatan & 237804 & 471503 & 6731 & 1962998 \\
\hline Dana tabarru' & 64615 & 104499 & 862 & 416681 \\
\hline
\end{tabular}

Sumber : Output Eviews 9 (2017, data diolah)

Pada Tabel 3 terlihat bahwa rata-rata nilai aset yang dimiliki perusahaan asuransi syariah pada periode 2012-2015 adalah sebesar 663277 juta rupiah dengan nilai maksimum mencapai 5 164388 juta rupiah dan nilai minimum sebesar 71504 juta rupiah. Besarnya standar deviasi pada aset yang dimiliki perusahaan asuransi jiwa syariah menunjukkan adanya perbedaan yang cukup besar dalam hal kepemilikan aset masing-masing perusahaan. Selain itu beban yang digunakan perusahaan memiliki rata-rata sebesar 130789 juta rupiah dengan nilai maksimum mencapai 647784 juta rupiah dan nilai minimum sebesar 2944 juta rupiah. Adapun pembayaran klaim yang telah dilakukan perusahaan asuransi jiwa syariah memiliki rata-rata sebesar 48465 juta rupiah dengan nilai maksimum mencapai 309402 juta rupiah dan nilai minimum sebesar 1382 juta rupiah.

Di sisi output pendapatan perusahaan mencapai nilai rata-rata sebesar 237804 juta rupiah dengan nilai maksimum mencapai 1962998 juta rupiah dan nilai minimum sebesar 6 731juta rupiah. Adapun dana tabarru' yang berhasil dihimpun oleh perusahaan asuransi jiwa syariah pada periode 2012-2015 memiliki rata-rata sebesar 64615 dengan nilai maksimum mencapai 416681 juta rupiah dan nilai minimum sebesar 862 juta rupiah. Besarnya standar deviasi pada pendapatan yang diperoleh perusahaan asuransi syariah mengindikasikan adanya perbedaan yang cukup besar dalam hal perolehan pendapatan masing-masing perusahaan asuransi jiwa syariah di Indonesia.

Dari hasil pengolahan data laporan keuangan 14 perusahaan asuransi jiwa syariah di Indonesia yang dijadikan sampel penelitian menunjukkan bahwa secara umum perusahaan asuransi jiwa syariah di Indonesia belum beroperasi secara efisien. Dapat dilihat pada Tabel 4 yang menunjukkan bahwa rata-rata skor efisiensi teknis mencapai 0.82 dan efisiensi teknis murni sebesar 0.86, sedangkan efisiensi skala memiliki skor 0,94. Nilai tersebut belum mencapai skor sempurna, yaitu 1. Hal ini mengindikasikan bahwa perusahaan asuransi syariah belum dapat beroperasi menggunakan kombinasi input yang optimal untuk memproduksi outputnya. Hasil ini sesuai dengan penelitian sebelumya yang dilakukan oleh Benarda et al. (2016)

Tabel 4 Efisiensi teknis perusahaan asuransi jiwa syariah di Indonesia periode 2013-2015

\begin{tabular}{lcccc}
\hline \multirow{2}{*}{ Efisiensi } & \multicolumn{4}{c}{ Tahun } \\
\cline { 2 - 5 } & 2013 & 2014 & 2015 & Rata-rata \\
\hline Efisiensi teknis & 0.83 & 0.8 & 0.85 & 0.82 \\
Efisiensi teknis muni & 0.85 & 0.84 & 0.89 & 0.86 \\
Efisiensi skala & 0.97 & 0.92 & 0.95 & 0.94 \\
\hline
\end{tabular}

Sumber : Output DEA (2017, diolah)

Selain mengestimasi skor efisiensi masing-masing perusahaan, metode DEA juga dapat memastikan bahwa suatu unit pengambil keputusan atau dalam hal ini perusahaan asuransi jiwa syariah sudah melakukan peningkatan kapasitas produksinya atau belum. Setiap unit pengambil keputusan akan berada pada salah satu kondisi return to scale yaitu decreasing 
return to scale (DRS), constant return to scale (CRS), dan increasing return to scale (IRS). Ketiga kondisi tersebut dapat dilihat pada Gambar 4.

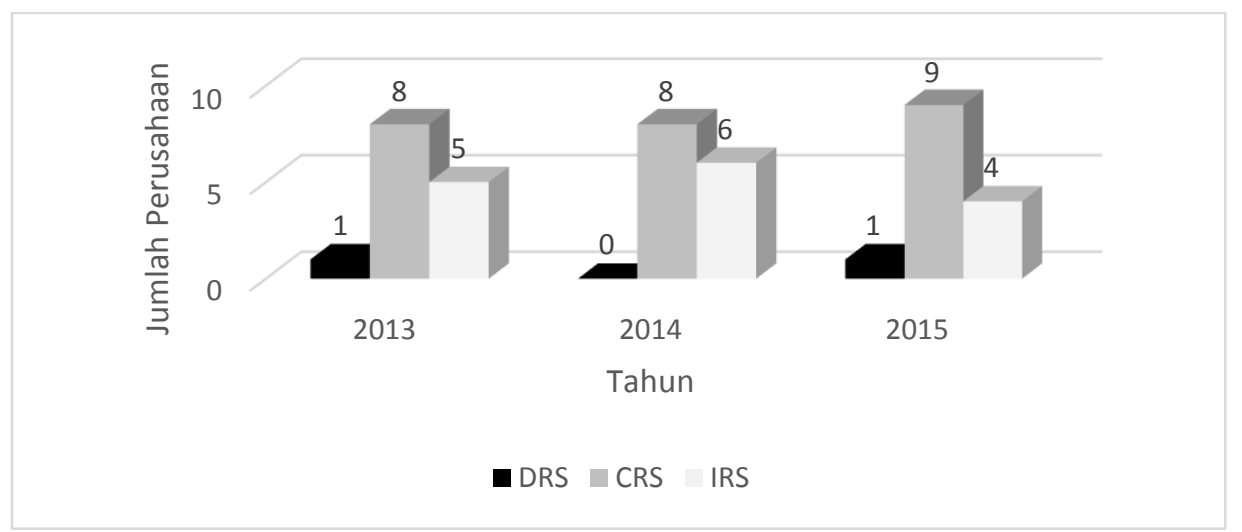

Sumber : Output DEA (2017)

Gambar 4 Kondisi return to scale perusahaan asuransi jiwa syariah

Pada Gambar 4 terlihat bahwa tren jumlah perusahaan asuransi jiwa syariah yang berada dalam kondisi CRS mengalami kenaikan dari 8 perusahaan di tahun 2013 dan 2014 menjadi 9 perusahaan di tahun 2015. Kondisi CRS tersebut mengindikasikan bahwa perusahaan asuransi jiwa syariah beroperasi pada the most productive scale size dimana perusahaan tersebut efisien secara teknis maupun teknis murni (Cooper et al. 2006). Di sisi lain jumlah perusahaan yang berada dalam kondisi IRS cenderung menurun sedangkan yang bearda dalam kondisi DRS cenderung konstan yaitu 1 perusahaan saja.

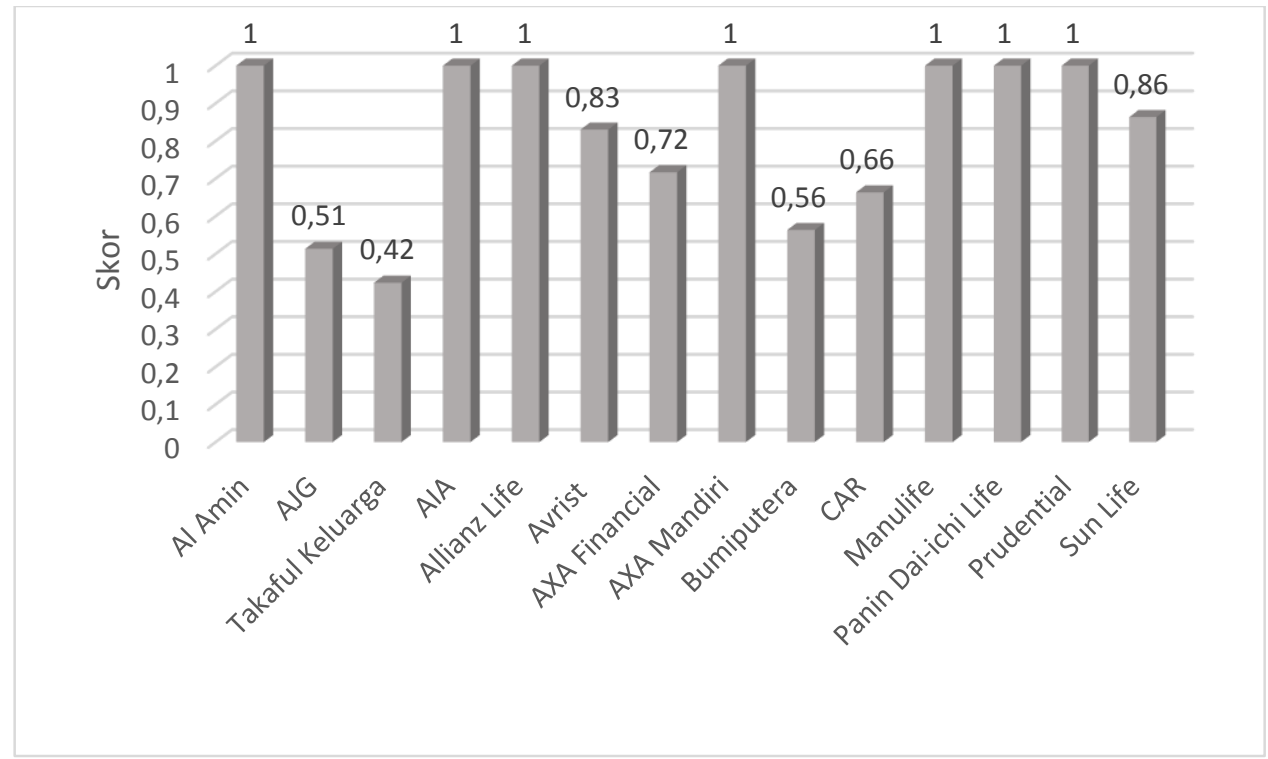

Sumber : Output DEA (2017, diolah)

Gambar 5 Pencapaian efisiensi teknis pada perusahaan asuransi jiwa syariah di Indonesia 
Efisiensi teknis keseluruhan (TE) dihasilkan dengan asumsi bahwa perusahaan asuransi jiwa syariah berada pada kondisi constan return to scale yang berarti setiap penambahan input $\mathrm{x}$ kali akan menghasilkan penambahan output $\mathrm{x}$ kali juga. Jika perusahaan memiliki skor TE sama dengan 1 maka dapat disimpulkan bahwa perusahaan tersebut efisien dan mampu mengombinasikan input optimal untuk memproduksi outputnya. Pada Gambar 5 memperlihatkan tingkat efisiensi teknis yang telah dicapai oleh masing-masing perusahaan asuransi jiwa syariah di Indonesia pada periode 2013-2015. Dari hasil pengolahan laporan keuangan 3 perusahaan asuransi jiwa syariah full fledge dan 11 unit usaha asuransi jiwa syariah menunjukkan bahwa Al Amin menjadi salah satu perusahaan asuransi jiwa syariah full fledge yang mencapai skor efisiensi teknis sempurna. Selain itu terdapat 6 unit asuransi jiwa syariah yang mencapai skor efisiensi teknis sempurna yaitu AIA, Allianz Life, AXA Mandiri, Manulife, Panin Dai-ichi Life dan Prudential. Di sisi lain Takaful Keluarga memiliki tingkat efisiensi teknis terendah.

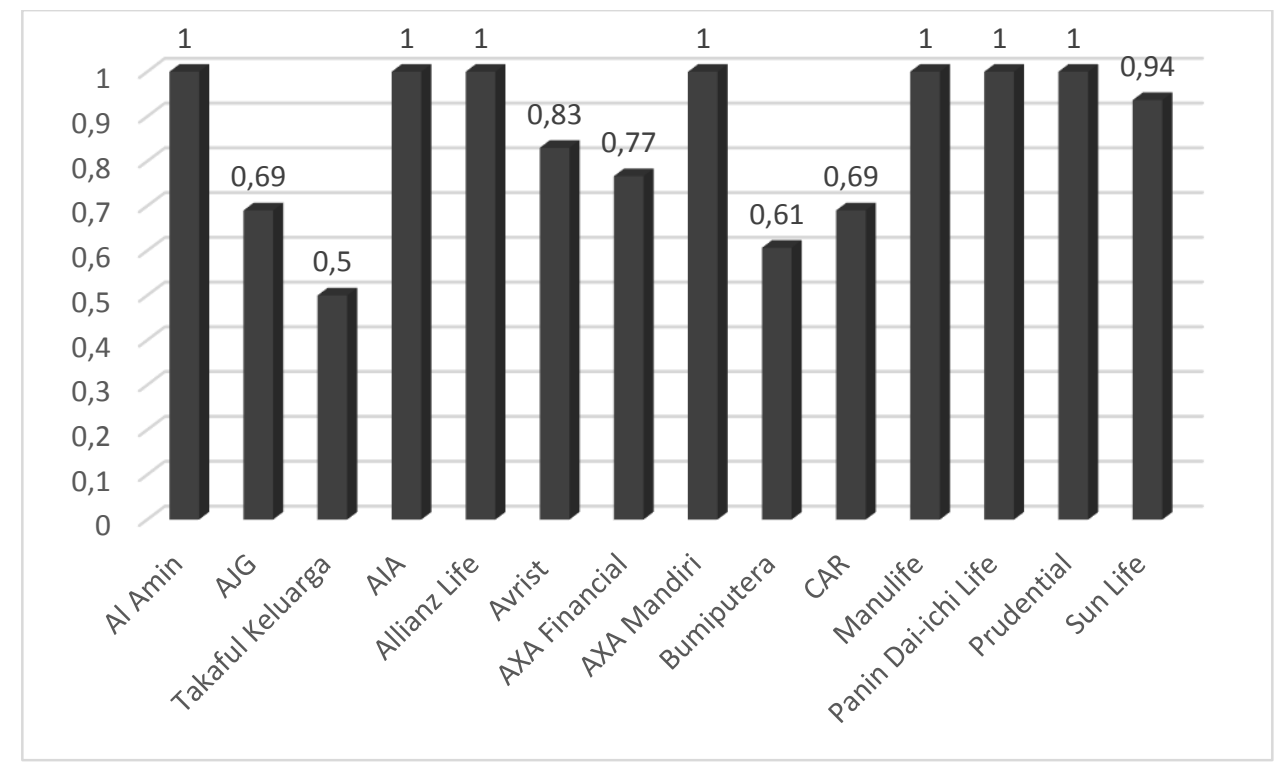

Sumber : Output DEA (2017, diolah)

\section{Gambar 6 Pencapaian efisiensi teknis murni pada perusahaan asuransi jiwa syaria di Indonesia}

Berbeda dengan efisiensi teknis secara keseluruhan, efisiensi teknis murni (PTE) dicapai dengan asumsi variable return to scale dimana penambahan input setiap $\mathrm{x}$ kali tidak mengakibatkan output akan bertambah sebesar x kali juga, akan tetapi bisa lebih kecil ataupun lebih besar. Pada Gambar 6 menunjukkan bahwa terdapat satu asuransi jiwa syariah full fledge dan 6 unit usaha asuransi jiwa syariah yang mencapai skor efisiensi sempurna. Namun sebagian perusahaan asuransi jiwa syariah belum mencapai skor sfisiensi teknis murni sempurna. Hal ini mengindikasikan bahwa mereka belum mampu mengombinasikan input optimalnya untuk menghasilkan output tertentu. Oleh karena itu dalam metode DEA ini selain mengestimasi skor efisiensi juga dapat menunjukkan potensi perbaikan (potential improvement) perusahaan asuransi jiwa syariah seperti yang ada pada Tabel 5. 
Tabel 5 Potential improvement perusahaan asuransi jiwa syariah (dalam juta rupiah)

\begin{tabular}{|c|c|c|c|c|c|c|}
\hline \multirow[t]{2}{*}{ Variabel } & \multicolumn{2}{|c|}{$\begin{array}{c}\text { Rata-rata } \\
\text { (orientasi output) }\end{array}$} & \multirow[t]{2}{*}{ Persen } & \multicolumn{2}{|c|}{$\begin{array}{c}\text { Rata-rata } \\
\text { (orientasi input) }\end{array}$} & \multirow[t]{2}{*}{ Persen } \\
\hline & Aktual & Target & & Aktual & Target & \\
\hline Aset & 649640 & 640130 & $1.46 \%$ & 649640 & 567924 & $12.58 \%$ \\
\hline Beban & 130465 & 129724 & $0.57 \%$ & 130465 & 121643 & $6.76 \%$ \\
\hline Pembayaran Klaim & 47398 & 45477 & $4.05 \%$ & 47398 & 41535 & $12.37 \%$ \\
\hline Pendapatan & 233326 & 254087 & $8.90 \%$ & 233326 & 233326 & $0.00 \%$ \\
\hline Dana tabarru' & 63213 & 71043 & $12.39 \%$ & 63213 & 63213 & $0.00 \%$ \\
\hline
\end{tabular}

Sumber : Output DEA (2017, diolah)

Tabel 5 menunjukkan bahwa dalam periode pengamatan, terdapat potensi perbaikan untuk perusahaan asuransi jiwa syariah agar dapat mencapai efisiensi baik dengan mengurangi input maupun meningkatkan output. Untuk mendeteksi sumber inefisiensi diperlukan dua pendekatan orientasi input dan orientasi output agar dapat diketahui input dan output mana yang harus ditingkatkan atau dikurangi (Benarda 2016). Pada rata-rata potential improvement orientasi input seharusnya asuransi jiwa syariah menurunkan asetnya sebesar $12.58 \%$, beban sebesar $6.76 \%$ dan meningkatkan dana tabarru' sebesar $12.37 \%$. Adapun pada orientasi output aset harus diturunkan sebesar $1.46 \%$, beban $0.57 \%$, pembayaran klaim $4.05 \%$ dan meningkatkan output berupa pendapatan sebesar $8.9 \%$ serta dana tabarru' $12.39 \%$.

Perusahaan asuransi jiwa syariah harus menurunkan variabel input yang berupa pembayaran klaim. Akan tetapi karena pembayaran klaim tersebut menggunakan dana tabarru', dimana dana tersebut merupakan milik peserta sehingga pada saat terjadi pengajuan klaim perusahaan asuransi syariah tidak diperbolehkan untuk menahan ataupun mengurangi klaim yang seharusnya dibayarkan. Oleh karena itu penurunan pembayaran klaim yang dimaksud bahwa perusahaan asuransi syariah harus memperbaiki proses underwriting sebelum menentukan besaran kontribusi yang harus dibayarkan oleh peserta asuransi.

\subsection{Asuransi Umum Syariah}

Sebelum masuk ke pembahasan efisiensi asuransi umum syariah di Indonesia berikut ini merupakan gambaran umum mengenai variabel input dan output dalam kegiatan operasional asuransi jiwa syariah di Indonesia yang kemudian akan digunakan untuk mengestimasi skor efisiensi. Sama halnya dengan asuransi jiwa syariah ada tiga input yang digunakan dalam penelitian ini yaitu aset, beban dan pembayaran klaim, sedangkan output yang digunakan yaitu pendapatan dan dana tabarru'. Tabel 6 menunjukkan input dan output yang digunakan dalam penelitian ini. 
Tabel 6 Statistik diskriptif input dan output perusahaan asuransi umum syariah periode 2013-2015 (dalam juta rupiah)

\begin{tabular}{lrrrr}
\hline \multicolumn{1}{c}{ Variabel } & Rata-rata & \multicolumn{1}{c}{$\begin{array}{l}\text { Standar } \\
\text { deviasi }\end{array}$} & $\begin{array}{c}\text { Nilai } \\
\text { Minimum }\end{array}$ & $\begin{array}{c}\text { Nilai } \\
\text { Maksimum }\end{array}$ \\
\hline Input : & & & & \\
\hline Aset & 137875 & 110087 & 26746 & 496564 \\
\hline Beban & 20544 & 22736 & 547 & 76921 \\
\hline Pembayaran klaim & 21959 & 24515 & 21 & 91182 \\
\hline Output : & & & 1487 & 100354 \\
\hline Pendapatan & 29088 & 26846 & 44 & 46296 \\
\hline Dana tabarru' & 11644 & 11759 & & \\
\hline
\end{tabular}

Sumber : Output Eviews 9 (2017, data diolah)

Pada Tabel 6 terlihat bahwa rata-rata nilai aset yang dimiliki perusahaan asuransi umum syariah pada periode 2012-2015 adalah sebesar 137875 juta rupiah dengan nilai maksimum mencapai 496564 juta rupiah dan nilai minimum sebesar 26746 juta rupiah. Selain itu beban yang digunakan perusahaan memiliki rata-rata sebesar 20544 juta rupiah dengan nilai maksimum mencapai 76921 juta rupiah dan nilai minimum sebesar 547 juta rupiah. Adapun pembayaran klaim yang telah dilakukan perusahaan asuransi jiwa syariah memiliki rata-rata sebesar 21959 juta rupiah dengan nilai maksimum mencapai 91182 juta rupiah dan nilai minimum sebesar 21 juta rupiah. Di sisi output pendapatan perusahaan mencapai nilai rata-rata sebesar 29088 juta rupiah dengan nilai maksimum mencapai 100354 juta rupiah dan nilai minimum 1487 juta rupiah. Adapun dana tabarru' yang berhasil dihimpun oleh perusahaan asuransi jiwa syariah pada periode 2012-2015 memiliki rata-rata sebesar 11644 dengan nilai maksimum mencapai 46296 juta rupiah dan nilai minimum sebesar 44 juta rupiah. Besarnya standar deviasi pada aset dan pendapatan yang diperoleh perusahaan asuransi umum syariah mengindikasikan adanya perbedaan yang cukup besar dalam hal perolehan pendapatan masingmasing perusahaan asuransi umum syariah di Indonesia.

Tabel 7 Efisiensi teknis perusahaan asuransi umum syariah di Indonesia periode 20132015

\begin{tabular}{lcccc}
\hline \multirow{2}{*}{ Efisiensi } & \multicolumn{5}{c}{ Tahun } \\
\cline { 2 - 5 } & 2013 & 2014 & 2015 & Rata-rata \\
\hline Efisiensi teknis & 0.71 & 0.78 & 0.65 & 0.71 \\
Efisiensi teknis muni & 0.79 & 0.85 & 0.77 & 0.80 \\
Efisiensi skala & 0.89 & 0.91 & 0.86 & 0.89 \\
\hline
\end{tabular}

Sumber : Output DEA (2017, diolah)

Hasil pengolahan data laporan keuangan 12 perusahaan asuransi umum syariah di Indonesia yang dijadikan sampel penelitian menunjukkan bahwa secara umum perusahaan asuransi umum syariah di Indonesia belum beroperasi secara efisien. Ditunjukkan pada Tabel 7 bahwa rata-rata skor efisiensi teknis mencapai 0.71 dan skor efisiensi teknis murni sebesar 0.80 , sedangkan efisiensi skala memiliki skor 0,89 . Hal ini mengindikasikan bahwa rata-rata perusahaan asuransi umum syariah belum dapat beroperasi menggunakan kombinasi input 
yang optimal untuk memproduksi outputnya, terbukti dari nilai efisiensi teknis murni yang lebih kecil jika dibandingkan nilai efisiensi skala.

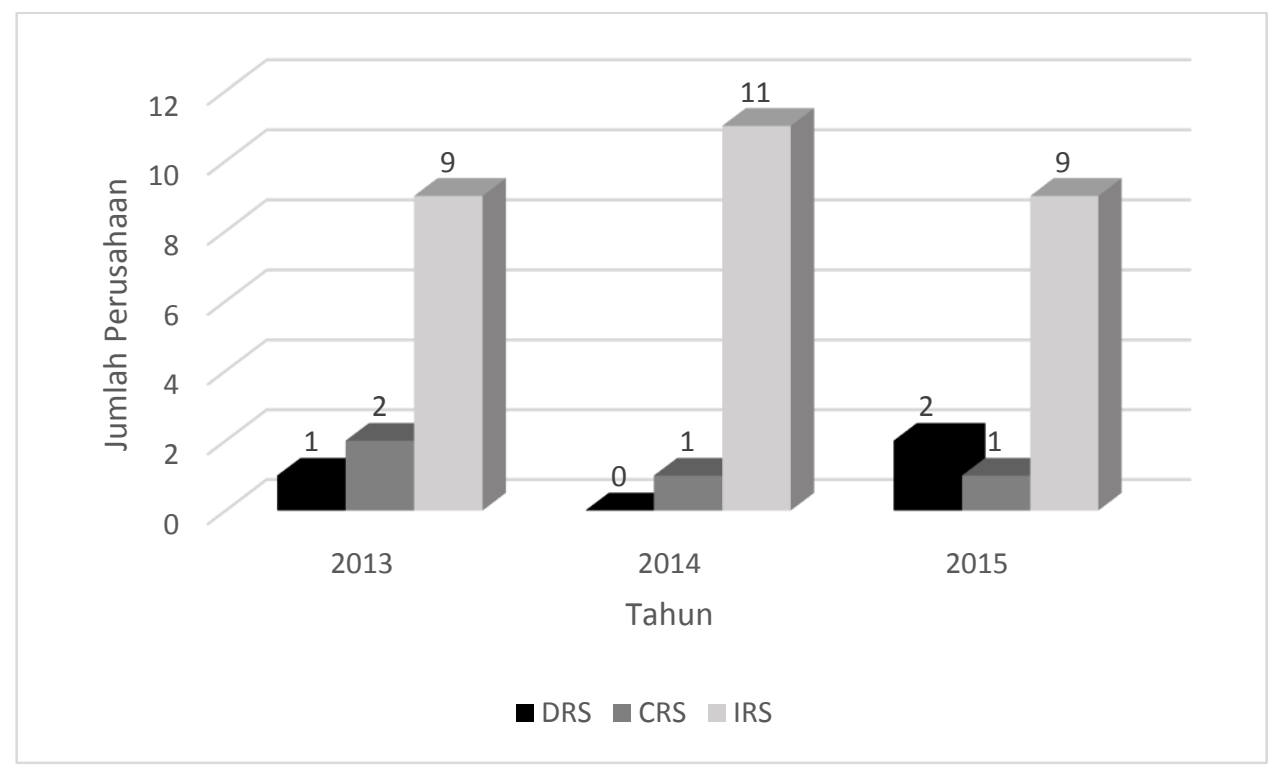

Sumber : Output DEA (2017)

\section{Gambar 7 Kondisi return to scale perusahaan asuransi umum syariah}

Jika dilihat dari kondisi return to scale, terlihat pada Gambar 7 bahwa mayoritas perusahaan asuransi umum syariah berada dalam kondisi increasing return to scale. Adapun perusahaan asuransi umum syariah yang berada dalam kondisi constan return to scale cenderung menurun yaitu hanya 1 perusahaan saja di tahun 2015, sedangkan yang berada dalam kondisi decreasing return to scale cenderung meningkat yaitu ada 2 perusahaan di tahun 2015. Kondisi increasing return to scale mengindikasikan bahwa setiap peningkatan input sebesar $1 \%$ akan menghasilkan peningkatan output yang besarnya lebih dari 1\%, asumsi cateris paribus. Hal ini sesuai dengan keadaan industri asuransi syariah di Indonesia yang masih berada dalam tahap pertumbuhan sehingga sangat responsif terhadap penambahan input karena skala usaha yang dijalankan masih tergolong kecil. Hal ini didukung dengan posisi aset industri asuransi syariah yang tergolong relatif kecil jika dibandingkan dengan industri asuransi nasional. 


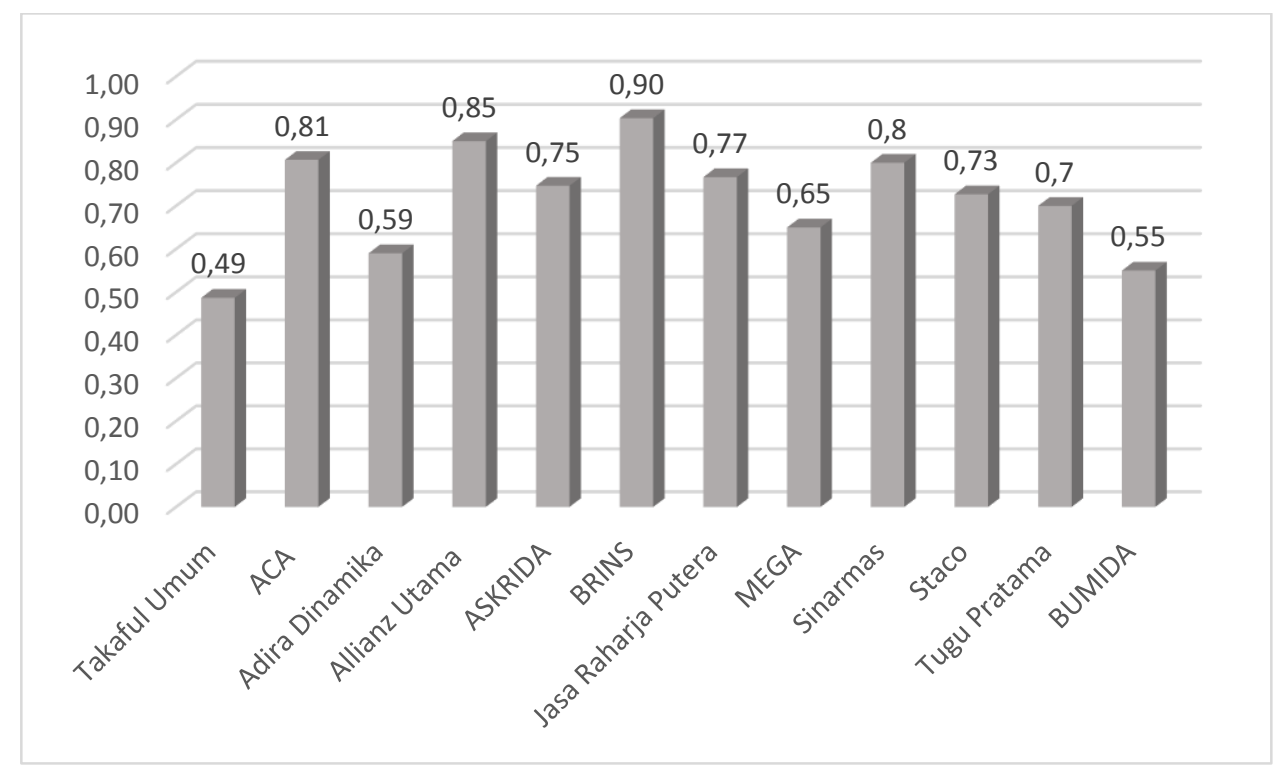

Sumber : Output DEA (2017, diolah)

\section{Gambar 8 Pencapaian efisiensi teknis pada perusahaan asuransi umum syariah di Indonesia}

Gambar 8 menunjukkan bahwa dari 12 perusahaan asuransi umum syariah yang terdiri dari satu perusahaan full fledge dan 11 unit usaha belum ada yang mencapai skor efisiensi teknis sempurna. Di sisi lain Gambar 9 menunjukkan bahwa terdapat tiga unit usaha asuransi umum syariah yang mencapai skor efisiensi teknis murni sempurna yaitu Allianz Utama, BRINS dan Jasa Raharja Putra.

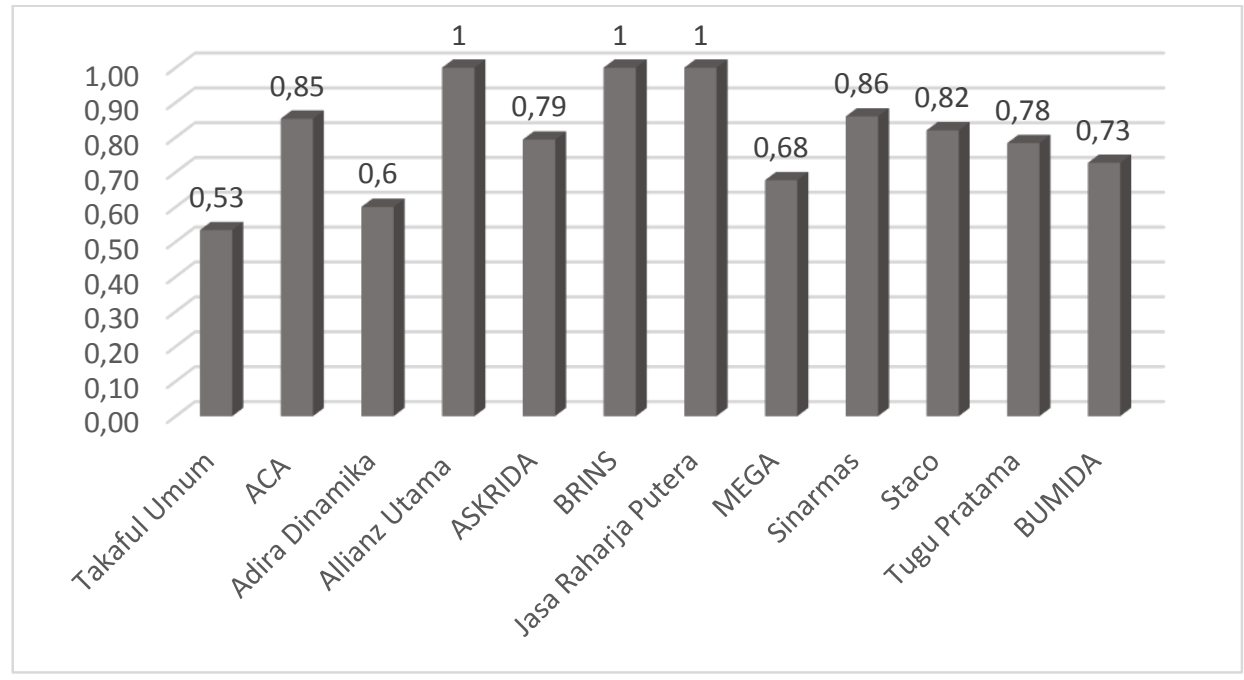

Sumber : Output DEA (2017, diolah)

\section{Gambar 9 Pencapaian efisiensi teknis murni pada perusahaan asuransi umum syariah di Indonesia}


Belum tercapainya efisiensi pada asuransi umum syariah dapat dikarenakan penggunaan input dengan jumlah berlebih atau dapat dikarenakan output yang dihasilkan kurang optimal sehingga akan menyebabkan inefisiensi. Adapun dalam menganalisis sumber inefisiensi pada perusahaan asuransi syariah diperlukan analisis dari dua pendekatan yaitu orientasi input dan orientasi output (Benarda et al. 2016). Tabel 8 menunjukkan bahwa sumber inefisiensi terbesar adalah dari perolehan dana tabarru'. Hal tersebut memiliki arti bahwa perusahaan asuransi syariah harus meningkatkan perolehan dana tabarru' sebesar $66.82 \%$. Hal ini dikarenakan dana tersebut yang nantinya akan digunakan untuk membayar klaim yang diajukan oleh peserta asuransi, sehingga ketersediaan dana tabarru' sangat penting bagi perusahaan asuransi syariah. Peningkatan jumlah dana tabarru' yang diperoleh dapat dilakukan dengan memperbaiki proses underwriting, pengelolaan investasi dana tabarru' yang baik dan menggencarkan promosi agar masyarakat mau berasuransi pada asuransi syariah.

Selain perolehan dana tabarru', variabel lain yang memiliki nilai perbaikan terbesar kedua yaitu pembayaran klaim sebesar $65.94 \%$. Hal ini mengindikasikan bahwa perusahaan asuransi syariah harus menurunkan pembayaran klaim sebesar $65.94 \%$. Akan tetapi karena pembayaran klaim tersebut menggunakan dana tabarru', dimana dana tersebut merupakan milik peserta sehingga pada saat terjadi pengajuan klaim perusahaan asuransi syariah tidak diperbolehkan untuk menahan ataupun mengurangi klaim yang seharusnya dibayarkan. Oleh karena itu penurunan pembayaran klaim yang dimaksud bahwa perusahaan asuransi syariah harus memperbaiki proses underwriting sebelum menentukan besaran kontribusi yang harus dibayarkan oleh peserta asuransi.

Di sisi lain jika dilihat dari hasil potential improvement sebaiknya perusahaan asuransi syariah memaksimalkan pencapaian output dengan penggunaan input yang ada karena peningkatan yang terjadi pada variabel output akan lebih signifikan dibandingkan jika perusahaan asuransi syariah meminimalkan penggunaan inputnya. Hal ini sejalan dengan kondisi mayoritas perusahaan asuransi syariah di Indonesia yang masih berada pada increasing return to scale yang sangat responsif terhadap penambahan input. Harapannya dengan adanya perbaikan pada variabel-variabel tersebut perusahaan asuransi syariah dapat mencapai tingkat efisien dalam memanfaatkan inputnya secara optimal untuk menghasilkan output.

Tabel 8 Potential improvement perusahaan asuransi umum syariah (dalam juta rupiah)

\begin{tabular}{ccccccr}
\hline \multirow{2}{*}{ Variabel } & \multicolumn{2}{c}{$\begin{array}{c}\text { Rata-rata } \\
\text { (orientasi output) }\end{array}$} & & \multicolumn{2}{c}{$\begin{array}{c}\text { Rata-rata } \\
\text { Persen }\end{array}$} & \multicolumn{2}{c}{ (orientasi input) } & \multirow{2}{*}{ Persen } \\
\cline { 2 - 3 } & Aktual & Target & & Aktual & Target & \\
\hline Aset & 137875 & 137188 & -0.50 & 137875 & 91865 & -33.37 \\
\hline Beban & 20544 & 20523 & -0.10 & 20544 & 12747 & -37.95 \\
\hline Pembayaran Klaim & 21959 & 11681 & -46.81 & 21959 & 7479 & -65.94 \\
\hline Pendapatan & 29088 & 46785 & 60.84 & 29088 & 29226 & 0.47 \\
\hline Dana tabarru' & 11645 & 19426 & 66.82 & 11645 & 12002 & 3.07 \\
\hline
\end{tabular}

Sumber : Output DEA (2017, diolah) 


\section{Simpulan dan Saran}

Secara umum kinerja efisiensi perusahaan asuransi jiwa syariah di Indonesia mencapai tingkat efisiensi rata-rata 0.82 untuk efisiensi teknis, efisiensi teknis murni 0.86 dan efisiensi skala sebesar 0.94. Begitu pula pada perusahaan asuransi umum syariah mencapai tingkat efisiensi dengan skor efisiensi teknis keseluruhan sebesar 0.71, efisiensi teknis murni sebesar 0.80 dan efisiensi skala sebesar 0.89. Oleh karena itu baik perusahaan asuransi jiwa syariah maupun asuransi umum syariah harus meningkatkan efisiensinya agar mampu bersaing dalam industri asuransi nasional. Berdasarkan hasil potential improvement yang ada, perusahaan asuransi syariah di Indonesia harus mengurangi penggunaan inputnya terutama pada aspek pembayaran klaim dengan cara memperbaiki proses underwriting sebelum menentukan besaran kontribusi yang harus dibayarkan oleh peserta asuransi. Selain itu untuk meningkatkan output berupa perolehan dana tabarru' dapat dilakukan dengan memperbaiki proses underwriting, pengelolaan investasi dana tabarru' yang baik dan menggencarkan promosi agar masyarakat memilih asuransi syariah.

\section{Daftar Pustaka}

Al-Amri K. 2015. Takaful insurance efficiency in the GCC countries. Humanomics, Vol.31 No.3, pp.344-353

Antonio MS, Ali MM, Akbar N. 2013. A comparative analysis of efficiency of takaful and conventional insurance in Malaysia. Hamdan Bin Mohammed e-University Journals.

[BCG] Boston Consulting Group. 2013. Indonesia's Rising Middle-Class and Affluent Consumers. Diunduh dari https://www.bcgperspectives.com/content/articles/center consumer customer insight c onsumer products indonesias rising middle class affluent consumers/ /at 3 Maret 2017

Benarda, Sumarwan U, Hosen MH. 2016. Tingkat Efisiensi Industri Asuransi Jiwa Syariah Menggunakan Pendekatan Two Stage Data Envelopment Analysis. Jurnal Aplikasi Bisnis dan Manajemen. Vol 2, No 1.

Coelli TJ, Rao DSP, O’Donnell CJ \& Battese, GE. 1998. An Introduction to Efficiency and Productivity Analysis.

Cooper WW,Seiford LM, Tone K. 2006. Introduction To Data Envelopment Analysis and Its Uses. USA : Springer.

[EY] Ernst \& Young Global Limited. 2014. Global Takaful Insight 2014 Market Update. EY Global Limited.

Farrell MJ. 1957. The Measurement of Productive Efficiency. Journal of the Royal Statistical Society. Vol 120, No 3.

[GA] Global Advisor. 2016. World Takaful Report. Diunduh dari https://www.google.co.id/url?sa=t\&rct=j\&q=\&esrc=s\&source=web\&cd=1\&cad=rja\&ua $\mathrm{ct}=8 \& \mathrm{ved}=0$ ahUKEwit66flgt VAhULM48KHZjCDfMQFggmMAA\&url=http\%3A\%2 F\%2Fwww.takafulprimer.com\%2Fmain\%2Fdownloads\%2Fms_5860.pdf\&usg=AFQjC NHy0Rcd8UMgjNPgLoG2anT5oBPhbQ/ 31 Maret 2017.

[IFSB] Islamic Financial Service Board. 2015. Islamic Financial Services Industry Stability Report.

Khan A, Noreen U. 2014. Efficiency Measure of Insurance v/s Takaful Firms Using DEA Approach: A Case of Pakistan. Islamic Economic Studies. Vol 22, No 1. 
Miniaoui H, Chaibi A. 2014. Technical Efficiency of Takaful Industry : A Comparative Study of Malaysia and GCC Countries. Working paper

[OJK] Otoritas Jasa Keuangan. 2015. Statistik Perasuransian. Diunduh dari. http://www.ojk.go.id/id/kanal/iknb/data-dan-statistik/asuransi/Default.aspx/ 3 Mei 2017

Rahman M.A. 2013. Comparative Study on the Efficiency of Bangladeshi Conventional and Islamic Life Insurance Industry: A Non-parametric Approach. Asian Business Review. Vol 2, No 3.

Ramadhani H. 2015. Prospek dan tantangan perkembangan asurasi syariah di Indonesia. Jurnal Ekonomi dan Bisnis Islam : AL-TIJARY, Vol. 01, No. 01, Desember 2015

Saad NM, Majid SA, Yusof R.M, Duasa J, Rahman ARA. 2006. Measuring Efficiency of Insurance and Takaful Companies in Malaysia using Data Envelopment Analysis (DEA). Review of Islamic Economics. Vol 10, No 2.

Tufahati H, Mardian S, Suprapto E. 2016. Pengukuran Efisiensi Asuransi Syariah dengan Data Envelopment Analysis (DEA). Jurnal Akutansi dan Keuangan Islam. Vol 4, No 1.

Envelopment Analysis (DEA). Jurnal Akutansi dan Keuangan Islam. Vol 4, No 1. 